the most likely interpretation of the findings is that there is no possibility of ensuring a universal intake of vitamin $D$ that will protect against rickets and eliminate the risk of hypercalcaemia. The administrative action taken in 1957 to reduce vitamin-D intakes has not resulted in an increase in rickets provided that the coloured immigrant population is separately considered. It remains speculative whether the decrease in hypercalcaemia noted from 1960 is a consequence of reduced vitamin-D intake.

The presence of rickets among coloured immigrants poses new problems which did not exist when the surveys started in 1953. From the evidence presented here and elsewhere (Arneil and Crosbie, 1963 ; Benson, Stroud, Mitchell, and Nicolaides, 1963 ) it would seem that an increased vitamin-D content of infant foods and cereals would not reach most of these infants at risk, most of whom are not offered dried milks or infant cereals. What is needed is a more determined effort to ensure that the mothers and caretakers of coloured infants are made aware of the needs of their children for vitamin-D supplementation. Whether the increased prevalence of rickets among immigrant children is due entirely to differences in feeding or whether the dark-skinned races are less able to benefit by Britain's capricious sunlight is not answered by this inquiry.

While the prevention of rickets should be the goal it remains important for those working in areas where there are immigrant infants to be alert to the possibility of rickets occurring and to have easily available the radiographic and chemical facilities needed to confirm the diagnosis.

\section{Summary}

The prevalence of infantile hypercalcaemia, nutritional rickets, and infantile scurvy has been investigated by the British Paediatric Association intermittently since 1953.
There is evidence of a decrease in prevalence of hypercalcaemia since 1960 which is not chronologically related to the reduction of vitamin-D intakes introduced in 1957.

Nutritional rickets is a problem of some magnitude in the children of coloured immigrants who do not receive protective amounts of vitamin $\mathrm{D}$ in infancy.

Infantile scurvy is related to feeding difficulties in the child or gross neglect by the parents.

These surveys would not have been possible without the co-operation of all the consultant paediatricians in Great Britain, and they are thanked for the trouble they have taken in submitting reports of their cases. The following members of the British Paediatric Association served on the relevant subcommittees during the survey periods: Dr. J. A. Black, Dr. F. S. W. Brimblecombe, Dr. C. F. Harris, Professor J. Hay, Dr. R. C. Lightwood, Professor R. A. McCance, Sir Wilfrid Sheldon, and Dr. S. Yudkin. Dr. (now Professor) T. Stapleton was responsible for the first hypercalcaemia survey and Dr. T. E. Oppé conducted the later surveys. They are indebted to Dr. E. W. Hart (Honorary Secretary, British Paediatric Association) for much help and encouragement, and to Drs. Dorothy Taylor and W. T. C. Berry, of the Ministry of Health, for valuable discussion.

\section{REFERENCES}

Arneil, G. C., and Crosbie, J. C. (1963). Lancet, 2, 423.

Benson, P. F., Stroud, C. E., Mitchell, N. J., and Nicol_ides, A. (1963). Brit. med. ., 1, 1054.

British Paediatric Association (1943). Arch. Dis. Childh., 18, 58.

- (1956). Brit. med. F., 2, 149.

Lightwood, R. C. (1952). Arch. Dis. Childh. 27, 302.

Ministry of Health (1957). Report of the Joint Subcommittee on Welfare Foods. H.M.S.O., London.

Stapleton, T., Macdonald, W. B., and Lightwood, R. (1957). Amer. F. clin. Nutr., 5, 533.

\title{
Study of the Vitamin-D Intakes of Infants in 1960
}

\author{
E. R. BRANSBY,* M.SC., PH.D.; W. T. C. BERRY,* M.D. ; DOROTHY M. TAYLOR,* M.D., D.P.H.
}

Brit. med. F., 1964, 1, 1661-1663

In their report in 1957 the Joint Subcommittee on Welfare Foods appointed by the Standing Medical Advisory Committees of Scotland and England recommended that the levels of vitamin $\mathrm{D}$ in National cod-liver-oil compound and in National dried milk, which are products available to young children under the Welfare Foods Scheme, should be reduced to 400 i.u. per teaspoonful and 90-100 i.u./oz. (3.2-3.5 i.u./g.) of dry powder respectively. At the same time the joint subcommittee suggested that the level of vitamin $D$ in infant cereals should be reduced to an average of 300 i.u./oz. (10.6 i.u./g.). The manufacturers of infant foods promptly agreed to reduce the content of vitamin $\mathrm{D}$ in their cereals in accordance with this suggestion and, in addition, the manufacturers of dried and evaporated milks undertook to arrange that the amount of vitamin $\mathrm{D}$ in their products intended for infant consumption was adjusted in accord with the joint subcommittee's recommendation on National dried milk.

The aim of the joint subcommittee was to bring about a substantial overall reduction in the amounts of vitamin $D$ consumed by infants, and to do so by adjusting the vitamin- $D$ content of each of the three main sources so that any one of

\footnotetext{
* Ministry of Health.
}

them consumed alone, while protecting against rickets, would not contain enough of the vitamin to render the total intake excessive and therefore liable to cause hypercalcaemia were all three sources taken concurrently. The joint subcommittee also drew attention to the fact that in 1951 a survey made for the Ministry of Health had shown that some children were reported to be receiving massive $(35,000$ i.u. daily) doses of vitamin $D$ from certain proprietary concentrates.

The main object of the present study was to assess the total intake of vitamin $\mathrm{D}$ by children in the first year of life from fortified dried milk, from infant cereals, from cod-liver oil, and from proprietary preparations of vitamin $D$, and, incidentally, the contribution to this total made by each source. At the same time the opportunity was taken to inquire into the medicinal preparations consumed by children up to 5 years of age. It may be said here that among the 1,185 older children sampled no case was encountered of massive dosage of the type that had been reported in 1951 .

\section{Method}

To achieve the object of the study it was necessary to obtain, from the mothers of an appropriate sample of children, infor- 
mation on the amounts of concentrated milk, infant foods, cereals, and vitamin-D preparations which they gave to their children during a single week.

In advance of the main study two pilot studies were made, the first in Luton and the second in Brighton; these were intended to develop and test a suitable method of investigation. Eventually, in order to get a national picture, a representative national sample of young children was obtained in two stages. First a random selection was made of 50 localities in which to conduct the study, and then a random selection was made either from the birth register or some other suitable source of children within each locality. The Social Survey (C.O.I.) kindly devised the child sampling procedures used in the main study and selected at random the localities in which the survey should be conducted: the random selection of the individual children was done in the departments of the medical officers of health for the localities concerned.

The information from mothers was collected by health visitors. The mothers were interviewed at home or at a clinic and were asked to provide information relating to the week prior to which the interview took place. The health visitors were provided with lists giving particulars of all products containing significant amounts of vitamin $\mathrm{D}$. Of the 1,623 mothers who were asked to co-operate only 10 refused to do so. Of 1,587 completed questionaries, 61 were excluded from the analysis because the feeding was abnormal during the survey week, and 34 because they related to children aged over 5 . The analysis was thus based on 1,492 survey records, of which 307 related to children under 1 . This ready acceptance of the study by the mothers and the comprehensiveness of the information supplied reflect the esteem in which health visitors are held by the communities which they serve.

The field work of the study was done in all but one of the 50) areas during February and March 1960. In the one remaining area it was done later in the same year. It should perhaps be pointed out that the survey took place before the changes in price of welfare foods which were made on 1 June 1961.

\section{Vitamin-D Content of Milks, Cereals, etc.}

The average value of 31 biological assays of dried milks performed for us was 125 i.u./oz. (4.4 i.u./g.) of powder. These were factory-fresh specimens, and we have assumed a value of 115 i.u., thus allowing for $10 \%$ deterioration before sale. We have assumed a value of 300 i.u./oz. (10.6 i.u./g.) of cereals and of 100 i.u./rusk, where these were fortified. Codliver oil is blended with great skill to give an average value of 400 i.u./teaspoonful ( 100 i.u./g.), and we therefore used that value. Proprietary medicinal preparations were assigned by us the value given on their label.

No allowance has been made in this study for the effects of waste, though waste is particularly apt to be high in infancy, and no allowance has been made for the tendency that many mothers have towards overstatement, particularly when questioned by health visitors about the nutrition of their children.

Because of factors such as these, all dietary-study findings need to be interpreted with reserve. In addition, it must be remembered that what was recorded was the assessed vitamin-D intake during a single week, whereas rickets certainly, and hypercalcaemia possibly, may take months to develop.

\section{Results}

The indings for children under 1 year relate to 307 children. The relatively small number (50) aged less than 3 months arose mainly out of the delays that occurred between the birth, notification, entry on the birth register, and the contact made by the health visitor for purposes of the survey.
Table I shows the numbers of children who took, or did not take, some source of vitamin D. Evidently in 1960 there were very few children who did not consume some vitamin $D$ at some stage during their first year.

TABLE I.-Number of Children Aged Up to 1 Year Taking or Not Taking Vitamin $D$ (From Fortified Milk, Infant Cereals, Welfare Cod-liver Oil, or Proprietary Preparations)

\begin{tabular}{|c|c|c|c|c|}
\hline \multicolumn{2}{|c|}{ Age } & Taking & Not Taking & Total \\
\hline $\begin{array}{l}<3 \text { months } \\
3- \\
6-\end{array}$ & $\begin{array}{ll}. & \\
\because & \\
\cdots & \cdots \\
. & \cdots\end{array}$ & $\begin{array}{l}38(76 \%) \\
80(98 \%) \\
82(99 \%) \\
83(90 \%)\end{array}$ & $\begin{array}{r}12 \\
2 \\
1 \\
9\end{array}$ & $\begin{array}{l}50 \\
82 \\
83 \\
92\end{array}$ \\
\hline & .. & $283(92 \%)$ & 24 & 307 \\
\hline
\end{tabular}

Table II shows the frequency with which each of the various vitamin-D sources figures in the diet. Where less than 50 i.u. was obtained from one source it has not been included. The Table shows that fortified milks and cereals form the sheetanchor of prevention against rickets, and that as the number of those taking dried or evaporated milks diminishes the number of those taking cereals tends to increase.

TABLE II.-Numbers of Children Stated to be Taking Various Sources of Vitamin $D$ in Amounts Above 50 i.u.

\begin{tabular}{|c|c|c|c|c|c|c|}
\hline \multirow{2}{*}{\multicolumn{2}{|c|}{ Age }} & \multicolumn{5}{|c|}{ Total Taking : } \\
\hline & & $\begin{array}{l}\text { Some } \\
\text { Source }\end{array}$ & $\begin{array}{c}\text { Dried or } \\
\text { Evaporated } \\
\text { Milk }\end{array}$ & Cereal & $\begin{array}{l}\text { Cod- } \\
\text { liver } \\
\text { Oil }\end{array}$ & $\begin{array}{l}\text { Prop. } \\
\text { Prep. }\end{array}$ \\
\hline $\begin{array}{l}<3 \text { months } \\
3- \\
6-12 " \\
9-12 "\end{array}$ & $\begin{array}{l}\ldots \\
\because \\
\cdots\end{array}$ & $\begin{array}{l}38 \\
80 \\
81^{*} \\
83\end{array}$ & $\begin{array}{l}34 \\
63 \\
55 \\
44\end{array}$ & $\begin{array}{r}9 \\
63 \\
75 \\
71\end{array}$ & $\begin{array}{r}4 \\
26 \\
27 \\
31\end{array}$ & $\begin{array}{l}7 \\
21 \\
16 \\
21\end{array}$ \\
\hline
\end{tabular}

* One excluded on grounds of incredibility of recorded intake of dried milk.

Table III shows vitamin-D intakes, with the averages of the highest and lowest quarters of the sample set out separately. There emerges a broad picture of the relative importance of the various sources. In the first three months of life the chief contribution to the lowest intakes is obviously made by milk, but in the second and the third three months the average figures mask the fact that of 16 cases with intakes below 300 i.u. the sole important source in all save two was cereals. In the

TABLE III.-Intakes of Vitamin D (i.u. Per Day) Consumed by Infants Taking Some Dietary Source

\begin{tabular}{|c|c|c|c|c|c|c|}
\hline \multirow[b]{2}{*}{ Age } & \multirow{2}{*}{$\stackrel{\text { All }}{\text { Consumers }}$} & \multicolumn{5}{|c|}{ I.U. per Day from } \\
\hline & & Milks & Cereals & $\mid \begin{array}{c}\text { Cod iver } \\
\text { Oil }\end{array}$ & $\begin{array}{l}\text { Prop. } \\
\text { Preps. }\end{array}$ & Total \\
\hline $\begin{array}{c}<3 \\
\text { months }\end{array}$ & $\begin{array}{l}\text { Lowest quarter } \\
\text { Middle half } \\
\text { Highest quarter }\end{array}$ & $\begin{array}{l}203 \\
320 \\
379\end{array}$ & $\begin{array}{r}2 \\
26 \\
121\end{array}$ & $\begin{array}{l}17 \\
16 \\
20\end{array}$ & $\begin{array}{r}0 \\
63 \\
204\end{array}$ & $\begin{array}{l}222 \\
424 \\
724\end{array}$ \\
\hline 3- months & $\begin{array}{l}\text { Lowest quarter } \\
\text { Middle half } \\
\text { Highest quarter }\end{array}$ & $\begin{array}{l}132 \\
416 \\
513\end{array}$ & $\begin{array}{l}104 \\
115 \\
226\end{array}$ & $\begin{array}{r}44 \\
114 \\
160\end{array}$ & $\begin{array}{r}41 \\
65 \\
268\end{array}$ & $\begin{array}{r}321 \\
710 \\
1,167\end{array}$ \\
\hline $6-$ & $\begin{array}{l}\text { Lowest quarter } \\
\text { Middle half } \\
\text { Highest quarter }\end{array}$ & $\begin{array}{l}124 \\
329 \\
305\end{array}$ & $\begin{array}{l}190 \\
262 \\
388\end{array}$ & $\begin{array}{r}36 \\
100 \\
238\end{array}$ & $\begin{array}{r}10 \\
49 \\
314\end{array}$ & $\begin{array}{r}360 \\
740 \\
1,245\end{array}$ \\
\hline $\begin{array}{c}9-12 \\
\text { months }\end{array}$ & $\begin{array}{l}\text { Lowest quarter } \\
\text { Middle half } \\
\text { Highest quarter }\end{array}$ & $\begin{array}{r}79 \\
223 \\
286\end{array}$ & $\begin{array}{l}141 \\
221 \\
363\end{array}$ & $\begin{array}{r}27 \\
164 \\
170\end{array}$ & $\begin{array}{r}16 \\
54 \\
524\end{array}$ & $\begin{array}{r}263 \\
662 \\
1,343\end{array}$ \\
\hline
\end{tabular}

average figures neither cod-liver oil nor proprietary preparations appear to make an important contribution to the lowest quarter of consumers, but in fact in 7 out of the 70 cases in the lowest quarter one or other of these two sources was the sole important contributor of vitamin D. At the upper end of the age scale proprietary preparations were the most important single factor in the highest intakes ; it may be noted, however, that a characteristic feature of this group is a tendency to take much milk and/or much cereal, together with, in many instances, full doses of medicinal preparations or cod-liver oil-that is, not drop doses as is advised on all bottles of welfare cod-liver oil. 


\section{Discussion}

In the light of our findings those of the British Paediatric Association can be interpreted and the decisions made by the Joint Advisory Subcommittee on Welfare Foods, 1957, can be judged. Below, discussion is limited to non-immigrants.

The paucity of rickets encountered by paediatricians, despite the rather low intakes of vitamin $\mathrm{D}$ of a quarter of the infants studied by us (Table III), is in keeping with experience in the United States (Jeans, 1950), where 100 i.u. daily has been found to prevent rickets. Because all cases of rickets are not seen by paediatricians we wrote to the medical officers of health of nine industrial cities, who replied giving the names of 10 children, not included in the British Paediatric Association (1964) report, as having developed rickets in 1960-1. The Chief Medical Officer of Scotland, who makes periodic inquiries in that country, learnt in the most recent inquiry that seven medical officers of health had encountered only six cases in the spring of 1963. Four of these were in Glasgow, where an increase in rickets was reported by Arneil and Crosbie (1963).

Obviously rickets is not common. There may have been some very small increase in prevalence, and indeed this is to be expected, because some babies are given fortified milks, cereals, and cod-liver oil in small amounts or intermittently. Such children might still have been safe before 1957 when such preparations contained so much more vitamin $\mathrm{D}$ than they do to-day. The British Paediatric Association noted that in $65 \%$ of cases of rickets a fortified milk had been fed. The amount or duration of feeding may well have been less than normal.

There is no obvious difference between the diets of the normal babies of our study and those reported by the paediatricians as having developed hypercalcaemia, but the paediatricians' reports are of necessity in less detail than ours.

But since the reductions in vitamin-D content of milks, cereals, and cod-liver oil, which in 1957 were followed eventually by a fall in the reported incidence in hypercalcaemia, the question must arise of whether the vitamin $D$ in these products should be yet further reduced in the hope of yet further improvements in the incidence of hypercalcaemia.

If this were done, those who are given occasional or inadequate amounts of milks, cereals, and medicinal preparations would be put at yet greater hazard than they are to-day.

If there is no other way of reducing hypercalcaemia a risk of rickets might have to be incurred; for, after all, it lies easily within the power of parents to protect their children from nutritional rickets if they are so disposed. But in the absence of adequate assurance of any resultant improvement in the incidence of hypercalcaemia it would seem sensible to concentrate first on measures to reduce the wide scatter of intakes of vitamin $\mathrm{D}$ shown in Table III.

Proprietary preparations were in our survey the most important single factor in the highest intakes. This was because certain proprietary preparations, in 1960, contained 800 i.u. or more in the daily dose recommended on their labels for infants. The manufacturers concerned readily agreed to make the necessary adjustments, so that the daily dose now contains 400 i.u. and their labels recommend that half doses be given where milks are fed. This change alone ought to suffice to bring the averages of the upper quarters, as recorded in our study, to below 1,000 i.u. More important, it should appreciably reduce the current incidence of hypercalcaemia if we are correct in assuming a causal relationship with vitamin-D intake.

But not all mothers abide by the directions on labels. Every bottle of welfare, and much other, cod-liver oil has on its label instructions that drop doses should be given only when dried milks are fed. Yet in the dietary study it was clear that this advice was sometimes ignored, and when the intake of dried milk and cereal was liberal this brought the total intake of vitamin $\mathrm{D}$ into the upper quarters. The mothers who did this may themselves have been liberally dosed with cod-liver oil in childhood, apparently with nothing but good effect. In spite of the caution of the British Paediatric Association (1964) in ascribing a causal role to vitamin $\mathrm{D}$ in hypercalcaemia, it would seem to be at least worth considering the addition to the labels of all medicinal preparations of vitamin D: "It is dangerous to exceed the recommended dose except on medical advice." It might also be useful, as well as being more consistent, if half the full dose of cod-liver oil, instead of drop doses, were recommended where fortified. milks are fed.

Thus at the upper end of the range of intakes the fault lies in overenthusiastic dosing and at the lower end in not dosing at all, or inadequately ; and a period of education and propaganda is clearly needed. At the same time further investigation may demonstrate the extent to which the residue of hypercalcaemia cases is due to doses of vitamin $D$ which, though harmless for 9,999 children, are not so to the ten-thousandth child. Finally, the possibility must not be forgotten that there may be some other difference between feeding practices in this and in other countries which may lead to our having a problem of hypercalcaemia where they do not. The intakes of vitamin $D$ observed by us would not be regarded as particularly high abroad. In France, for example, 1,000 i.u. daily, or in certain special cases 1,500 i.u., is advocated by the public health service; and in Holland, up to $1960,50 \%$ of paediatricians were prescribing 300 to 1,000 i.u. daily of vitamin $D$ in addition to vitaminized baby foods (Ruys, 1964). Yet these countries appear to have little hypercalcaemia.

Finally, the decisions of the Welfare Foods Subcommittee have stood the test of time. Intakes of vitamin $D$ have been reduced, the incidence of hypercalcaemia has been more than halved, and there has been little or no increase in rickets.

\section{Summary}

The intakes of vitamin D of normal infants in 1960 are reported.

Average intakes ranged from about 250 to about 1,200 i.u. daily for the quarters of the population surveyed who consumed least and most vitamin $D$.

The data are discussed in relation to those from the British Paediatric Association (1964), which indicate that the incidence of hypercalcaemia has more than halved with little or nc increase in the incidence of rickets.

Measures which have or could be taken are discussed.

We would like to express our debt to Dr. T. Oppé, of the Britısh Paediatric Association, who was responsible for the collection of the data on hypercalcaemia and rickets on which we have so extensively drawn in this paper, and to the paediatricians who provided the material. We would like to acknowledge the kindness of the British Paediatric Association for allowing us to use all this information. Without all this help it would not have been possible fully to interpret our dietary findings. We are grateful also for the co-operation from M.O.H.s and health visitors, without which our study would have been impracticable. We should also like to report that the manufacturers of medicinal preparations of vitamin D undertook with the utmost readiness the reformulation and relabelling of their products.

\section{REFERENCES}

Arneil, G. C., and Crosbie, J. C. (1963). Lancet, 2, 423. British Paediatric Association (1964). Brit. med. F., 1, 1659. Jeans, P. C. (1950). F. Amer. med. Ass., 143, 177.

Ministry of Health (1957). Report of the Joint Subcommittee or. Weltare Foods. H.M.S.O., London.

Ruys, J. H. (1964). Maandschr. Kindergeneesk. In press. 